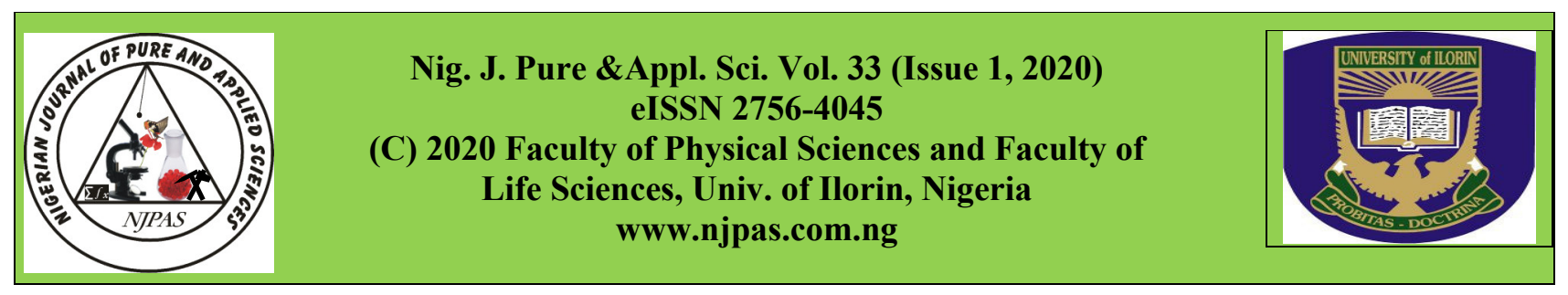

doi: http://dx.doi.org/10.48198/NJPAS/19.B07

\title{
PREVALENCE AND INTENSITY OF URINARY SCHISTOSOMIASIS AMONG RESIDENTS ALONG RIVER BENUE, ADAMAWA STATE, NIGERIA
}

${ }^{1}$ Department of Biology, School of Sciences, Adamawa State College of Education, Hong, Hong Local Government Area, Adamawa State, Nigeria.

${ }^{2}$ Department of Zoology, School of Life Sciences, Modibbo, Adama University of Technology, Yola. Adamawa state Nigeria.

\section{ABSTRACT}

In Nigeria, infection caused by Schistosoma haematobium has been known to be endemic especially among residence along Rivers. This study was a cross-sectional that involved 1,404 participants in ten (10) communities across five Local Government Areas (LGA) in question, they were randomly selected from July to September 2016 and from February to April 2017. Urine samples collected were examined using sedimentation technique while intensity was ascertained as eggs $/ 10 \mathrm{mls}$ of urine and values were expressed as Mean \pm SD. Data on demography were obtained by structured questionnaires and was computed using SPSS version 22. Out of the overall prevalence and intensity of Urinary schistosomiasis $23.2 \%$ and $513 \pm 0.05$ eggs $/ 10 \mathrm{mls}$ of urine that were recorded, Kabawa had (12.4\% and $80 \pm 0.02)$ prevalence and intensity of urinary schistosomiasis and lowest in Kangle $(12.3 \%$ and $24 \pm 0.82 \mathrm{eggs} / 10 \mathrm{ml})$ with significance association between intensity of urinary schistosomiasis and community $(\mathrm{p}<0.05)$. However, Gender related prevalence and intensity revealed $25.5 \%$ and $289 \pm 4.66 \mathrm{eggs} / 10 \mathrm{ml}$ as the highest while, $20.8 \%$ and $206 \pm 4.49 \mathrm{eggs} / 10 \mathrm{ml}$ were recorded as the lowest among males and females respectively. Furthermore, prevalence and intensity by age shows that, participants within age bracket 5-14 years old had the highest prevalence and intensity of urinary schistosomiasis $(36.6 \%)$ and $(142 \pm 0.005$ eggs $/ 10 \mathrm{ml})$ respectively. While, low prevalence and intensity urinary schistosomiasis was recorded among age group 45-54years old $9.0 \%$ with $(42 \pm 0.040$ eggs $/ 10 \mathrm{mls})$. Subjects fetching from River/Streams had high prevalence and intensity of schistosomiasis compare to borehole fetchers $13.8 \%$ and $241 \pm 0.302 \mathrm{egg} / 10 \mathrm{ml}$ of urine, $31.8 \%, 46 \pm 0.080 \mathrm{egg} / 10 \mathrm{ml}$ of urine and respectively. Occupational related prevalence and intensity was highest among Fishers with $35.0 \%$ and $188 \pm 0.012$ egg $/ 10 \mathrm{ml}$ of urine while, lowest prevalence and intensity were recorded among Business men $4.8 \%$, and $36 \pm 0.020 \mathrm{egg} / 10 \mathrm{ml}$ of urine among Civil servants. In conclusion, this study has shown moderate prevalence and intensity of urinary schistosomiasis, therefore, chemotherapy and Health Education should be advocated from time to time across the study area.

Keywords: Prevalence, Intensity, Urinary Schistosomiasis and River-Benue

\section{Introduction}

Schistosomiasis remains one of the most prevalent neglected tropical diseases especially in Nigeria which has the greatest number of infected people worldwide (Salwa et al., 2016). The intensity had 
high morbidity among Children, Adolescents and Young Adults (Hotez et al., 2009). Thus, the negative Impacts on School and the debilitation cause by untreated infections demoralize both social and economic development in endemic Page | 3578 Area (Vanderwerf et al., 2003)

Schistosomiasis is an acute and chronic parasitic disease caused by blood flukes (trematode worms) of the genus Schistosoma. Estimates show that at least 206.4 million people required preventive treatment in 2016. Preventive treatment which should be repeated over a number of years, will reduce and prevent morbidity. Urinary schistosomiasis transmission has been reported from 78 countries. However, preventive chemotherapy for schistosomiasis, where people and communities are targeted for large-scale treatment, is only required in 52 endemic countries with moderate-to-high transmission, with estimated 101 million persons at risk and 26 million people infected (WHO, 2018). According to Chitsulo et al. (2010), transmissions and contact activities varies between the communities in many areas. Mostata et al. (2009) reported that, urinary schistosomiasis had the risk of causing haematuria, dysuria nutritional deficiencies, lesion of the bladder, kidney failure and elevated risk of bladder cancer and in children, growth retardations are well established. Finally, the work capacity of rural inhabitants has drastically reduced because of the weakness caused by the parasites. It is estimated that over 240 million people are infected, with about 700 million people worldwide at risk of infection.

According to Ivoke, et al. (2014) the prevalence of infection was significantly higher among male participants compared to females and this is consistent with previous reports in Nigeria. The presence of large body of water across the state and construction of dam seems to increase the human contact and thus increase the risk of schistosomiasis. Despite such problems schistosomiasis has to be studied among residents along River Benue.
Accordin to Hotez and Kamth (2009), Schistosomesare transmitted through snail intermediate host while some snail that serves as intermediate host of shistosome and fasciola are as follows: Bulinus spp (Schistosoma intercalatum, and S. haematobium), Oncomeelania spp (S. japanicum), Biomphalaria spp (S. mansoni), Lymnaea spp (Fasciola hepatica) and Segmentina spp (F. buski).

\section{Materials and Methods}

The study was conducted in Adamawa State which is located in the north eastern part of Nigeria. It lies between latitude $7^{0}$ and $11^{\circ} \mathrm{N}$ of the equator and between longitude $11^{\circ}$ and $14^{0}$ east of Greenwich Meridian. It shares boundary with Taraba State to the South and with Gombe State to the West, it also shares boundary with Borno State to Northwest and international boundary with Cameroun republic to the East. The State covers a land mass of about 38.741 square kilometers, having mountainous land with River Benue, Gongola and Yadzaram running from the North to the South (Adebayo and Tukur, 1999). The total population of the State according to (National Population Census, 2006) was 3, 178,950 with 1, 607,270 males and 1, 572,680 females.

\section{Study Site}

The study was carried out in 10 communities selected across 5 LGAs along River Benue in Adamawa State. The selection was based on the population and the proximity of the community to the river Benue shore, which includes Fofure (Ribadu and Dulo), Girei (Labondo and Kangle), Demsa (Zuran and Kwale), Numan (Bandawa and Kanti) and Lamurde (Kabawa and Hoki).

\section{Population of the Study}

Population of the study was randomly selected from communities along river Benue which includes children and adults, males and females of different occupations across ten communities of the study Area. Children who could not control 
their bowel and urine were not enrolled into the study this was the screening criteria for sample collections. All adult participants were given consent form, Parents and guardians verbalconsent on behalf of their children and wards. Children

Page | 3579 over 12 years of age were given consent form as well. One thousand four hundred and four $(1,404)$ volunteers were randomly selected across the LGAs.

\section{Sampling and Sample Collection}

A well labeled specimens bottles were given to One thousand four hundred and four $(1,404)$ participants, and they were instructed on how to collect their urine samples without contamination, the samples were immediately preserved with $1 \%$ household bleach (Ladan et al., 2011) and was conveyed to Agape Medical laboratory and Diagnosis Yola and Institute of Infectious Disease for Poverty (IIDP) Laboratory Modibbo Adama University of Technology, Yola, for Macroscopy and Microscopy. Basically, sedimentation technique was adopted for the isolation of terminal spine ova of $S$. haematobium (Cheesbrough, 2006). Each participant was given a structured demographic questionnaire as regard to information about name, sex, age, location, educational qualification.

\section{Ethical Clearance of the Study}

The present study was carried out according to the guidelines and permission of Adamawa State Ministry of Health, Yola and the Village heads of communities involved. While seeking the consent from the research participants in each village, the objectives and procedures of the study were clearly explained to them in the local language, thus, written informed consents forms were given to all the adult participants and guardians/parents of the children before starting the survey. All the infected individuals were treated with a single dose of $40 \mathrm{mg} / \mathrm{kg}$ body weight of praziquantel under the supervision of a satisfied medical practitioner.

\section{Data Analysis}

Data were analyzed with SPSS, version 22. Simple percentage, Chi-square test and mean $\pm \mathrm{SD}$ were used to analyze the intensity, differences, association of the findings. $p<0.05$ was considered as significant while, $\mathrm{p}>0.05$ as insignificant.

\section{RESULTS}

The prevalence and intensity of urinary schistosomiasis by gender across the community shown in table 1 revealed that, out of 10 community sampled, $23.2 \%$ and $513 \pm 0.05$ eggs $/ 10 \mathrm{mls}$ prevalence and intensity were recorded, however, among the communities, Ribado had the highest prevalence of $30.0 \%$ with intensity of $72 \pm 0.12 \mathrm{eggs} / 10 \mathrm{ml}$ of urine. With this breakdown, Kabawa had 23.5\% prevalence with high intensity of $80 \pm 0.02$ eggs $/ 10 \mathrm{mls}$ of urine, while lowest prevalence and intensity of urinary schistosomiasis were recorded in Hoki $15.7 \%$ and Kangle $24 \pm 0.82$ eggs $/ 10 \mathrm{mls}$ of urine, this signifies association between prevalence and intensity of urinary schistosomiasis amongst the community in question $(\mathrm{p}<0.05)$. It has also been showed that, males had the highest prevalence and intensity of infection than their female counterpart irrespective of the community with $25.5 \%, 289 \pm 4.66$ eggs $/ 10 \mathrm{mls}$ of urine and $20.8 \%, \quad 206 \pm 4.49$ eggs/10mls of urine with no statistical difference $(\mathrm{p}>0.05)$. Prevalence and intensity by age bracket showed $36.6 \%$ and $142 \pm 0.005$ eggs $/ 10 \mathrm{mls}$ of urine among age bracket 5-14 years old, with lowest prevalence and intensity among age group 45-54 $(9.0 \%$ and $42 \pm 0.040$ eggs $/ 10 \mathrm{mls}$ of urine). However, Chi-square analysis indicates significant difference between prevalence and intensity in relation to age group $(\mathrm{p}<0.05)$.

Tables 2, presented many varieties of predisposing factors surrounding the participants which prone them to urinary schistosomiasis, this includes; Occupation, Source of water, Season of the year, Gender differences and their school background, The prevalence and occurrence of urinary 
schistosomiasis in relation to the participants' source of water has revealed that, out of 362 subjects that drink from Borehole, 13.8 and $46 \pm 0.080$ eggs $/ 10 \mathrm{mls}$ of urine were recorded, those drinking from wells had $112(21.3 \%)$ and

Page | $3580226 \pm 0.981 \mathrm{eggs} / 10 \mathrm{mls}$ of urine, while participants that patronized Rivers and Streams as source of water had the highest prevalence and intensity of $164(31.8 \%)$ and $46 \pm 0.302 \mathrm{eggs} / 10 \mathrm{mls}$ of urine.
This finding has showed association between prevalence and intensity in relation to source of drinking water $(\mathrm{P}<0.05)$. High prevalence was observed in wet season $28.8 \%$ with intensity of $204 \pm 0.221$ while, highest intensity $254 \pm 0.032$ eggs $/ 10 \mathrm{mls}$ of urine was observed in dry season with $17.7 \%$ prevalence, and there was significance relationship between urinary schistosomiasis infections and season $(\mathrm{p}<0.05)$.

Table 1: Distribution and Intensity of Urinary Schistosomiasis in relation to Location, Gender and Age in the study Area

\begin{tabular}{|c|c|c|c|c|c|c|c|c|c|c|}
\hline \multirow{3}{*}{ S/No } & \multirow[t]{3}{*}{ Location } & \multirow{3}{*}{$\begin{array}{l}\text { No. } \\
\text { Examined }\end{array}$} & \multirow{3}{*}{$\begin{array}{l}\text { Prevalence } \\
(\%)\end{array}$} & \multirow{3}{*}{$\begin{array}{l}\text { P. } \\
\text { value }\end{array}$} & \multirow{3}{*}{$\begin{array}{l}\text { Eggs/10mls } \\
\text { Mean } \\
\text { intensity }\end{array}$} & \multirow{3}{*}{$\begin{array}{l}\text { P. } \\
\text { value }\end{array}$} & \multicolumn{4}{|c|}{ Gender } \\
\hline & & & & & & & \multicolumn{2}{|c|}{ Male } & & \multirow{2}{*}{$\begin{array}{l}\text { Female } \\
\text { Intensity }\end{array}$} \\
\hline & & & & & & & $\begin{array}{l}\text { Prevalence } \\
(\%)\end{array}$ & Intensity & $\begin{array}{l}\text { Prevalence } \\
(\%)\end{array}$ & \\
\hline l & Dolo & $120(8.5)$ & $35(29.2)$ & 0.03 & $31 \pm 0.34$ & 0.88 & $21(17.5)$ & $25 \pm 0.66$ & $14(11.7)$ & $13 \pm 052$ \\
\hline 2 & Ribado & $120(8.5)$ & $36(30.0)$ & 0.01 & $72 \pm 0.12$ & $0.03 *$ & $18(15.0)$ & $39 \pm 0.52$ & $18(15.0)$ & $33 \pm 0.35$ \\
\hline 3 & Labondo & $240(17.1)$ & $58(21.6)$ & 0.21 & $38 \pm 0.91$ & 0.07 & $19(7.9)$ & $27 \pm 0.55$ & $39(16.3)$ & $11 \pm 0.05$ \\
\hline 4 & Kangle & $180(12.8)$ & $39(21.6)$ & 0.00 & $24 \pm 0.82$ & 0.06 & $27(15.0)$ & $15 \pm 0.34$ & $12(6.7)$ & $9 \pm 0.28$ \\
\hline 5 & Zuran & $96(6.8)$ & $25(26.0)$ & 0.12 & $52 \pm 0.23$ & 0.12 & $10(10.4)$ & $29 \pm 0.19$ & $15(15.6)$ & $23 \pm 0.49$ \\
\hline 6 & Kwale & $96(6.8)$ & $26(27.0)$ & 0.22 & $77 \pm 0.44$ & 0.25 & $13(13.5)$ & $35 \pm 0.20$ & $13(13.5)$ & $42 \pm 0.31$ \\
\hline 7 & Bandawa & $174(12.4)$ & $38(21.8)$ & 0.06 & $51 \pm 0.33$ & $0.01^{*}$ & $14(8.0)$ & $27 \pm 0.12$ & $24(13.8)$ & $24 \pm 102$ \\
\hline 8 & Kanti & $174(12.4)$ & $29(16.7)$ & 0.01 & $29 \pm 0.94$ & 0.06 & $20(11.5)$ & $13 \pm 0.63$ & $9(5.2)$ & $16 \pm 0.23$ \\
\hline 9 & Kabawa & $102(12.4)$ & $24(23.5)$ & 0.03 & $80 \pm 0.02$ & 0.18 & $11(10.8)$ & $54 \pm 0.59$ & $13(12.7)$ & $26 \pm 0.34$ \\
\hline \multirow[t]{2}{*}{10} & Hokil & $102(12.4)$ & $16(15.7)$ & 0.11 & $34 \pm 0.35$ & 0.20 & $11(10.8)$ & $25 \pm 0.14$ & $5(4.9)$ & $9 \pm 0.29$ \\
\hline & Total & $1404(100)$ & $326(23.2)$ & & $513 \pm 0.05$ & & $164(11.7)$ & $289 \pm 4.66$ & 162(11.5) & $206 \pm 4.49$ \\
\hline 1 & $5-14$ & $344(24.5)$ & $126(36.6)$ & 0.02 & $142 \pm 0.005$ & $0.02^{*}$ & $87(25.3)$ & $90 \pm 1.020$ & $39(11.3)$ & $52 \pm 0.440$ \\
\hline 2 & $15-24$ & $320(22.8)$ & $95(29.7)$ & 0.11 & $100 \pm 0.045$ & 0.07 & $66(20.6)$ & $71 \pm 0.234$ & $29(9.1)$ & $29 \pm 0.431$ \\
\hline 3 & $25-34$ & $268(19.9)$ & $43(16.0)$ & 0.17 & $94 \pm 0.0311$ & 0.13 & $23(8.6)$ & $52 \pm 0.933$ & $20(7.5)$ & $42 \pm 0.341$ \\
\hline 4 & $35-44$ & $158(11.3)$ & $19(12.0)$ & 0.43 & $59 \pm 0.981$ & 0.11 & $6(3.8)$ & $43 \pm 0.600$ & $13(8.2)$ & $16 \pm 0.001$ \\
\hline 5 & $45-54$ & $119(8.5)$ & $18(9.0)$ & 0.22 & $42 \pm 0.040$ & 0.19 & $8(6.7)$ & $25 \pm 0.414$ & $10(8.4)$ & $18 \pm 0.231$ \\
\hline \multirow[t]{2}{*}{6} & $55 \&$ above & $115(8.2)$ & $25(21.7)$ & 0.50 & $73 \pm 0.027$ & 0.15 & $17(14.8)$ & $50 \pm 0.544$ & $8(6.9)$ & $23 \pm 0.074$ \\
\hline & Total & $1404(100)$ & $326(23.2)$ & & $513 \pm 0.05$ & & $207(14.7)$ & $331 \pm 4.66$ & $119(8.5)$ & $180 \pm 4.49$ \\
\hline
\end{tabular}

*Significant $(\mathrm{p}<0.05)$ 
Table 2: Prevalence and Intensity of Urinary Schistosomiasis by Predisposing factors in the Study Area

\begin{tabular}{|c|c|c|c|c|c|c|c|c|c|c|c|}
\hline \multirow{2}{*}{ Page | $3581^{-}$} & \multirow[t]{2}{*}{ S/No } & $\begin{array}{l}\text { Predisposition } \\
\text { Factors }\end{array}$ & \multirow[t]{2}{*}{$\begin{array}{l}\text { No. } \\
\text { Examined }\end{array}$} & \multirow[t]{2}{*}{$\begin{array}{l}\text { Prevalence } \\
\text { (\%) }\end{array}$} & \multirow[t]{2}{*}{$\begin{array}{l}P . \\
\text { value }\end{array}$} & \multirow{2}{*}{$\begin{array}{l}\text { Eggs/10mls } \\
\text { Mean } \\
\text { intensity }\end{array}$} & \multirow[t]{2}{*}{$\begin{array}{l}\text { P. } \\
\text { value }\end{array}$} & Male & \multicolumn{2}{|c|}{ Gender } & Female \\
\hline & & $\begin{array}{l}\text { Source of } \\
\text { water }\end{array}$ & & & & & & $\begin{array}{l}\text { Prevalence } \\
(\%)\end{array}$ & Intensity & $\begin{array}{l}\text { Prevalence } \\
\text { (\%) }\end{array}$ & Intensity \\
\hline & 1 & Borehole & $362(25.8)$ & $50(13.8)$ & 1.04 & $46 \pm 0.080$ & 0.12 & $27(7.5)$ & $21 \pm 0.620$ & $23(6.4)$ & $25 \pm 1.200$ \\
\hline & 2 & Well & $526(37.5)$ & $112(21.3)$ & 0.9 & $226 \pm 0.981$ & 0.32 & $50(9.5)$ & $105 \pm 1.022$ & $62(11.8)$ & $121 \pm 0.321$ \\
\hline & 3 & $\begin{array}{l}\text { River/ } \\
\text { Stream }\end{array}$ & $516(36.8)$ & $164(31.8)$ & $0.04^{*}$ & $241 \pm 0302$ & 0.11 & $98(19.9)$ & $150 \pm 0.120$ & $66(12.8)$ & $91 \pm 0.021$ \\
\hline & & $\begin{array}{l}\text { Total } \\
\text { Season }\end{array}$ & $1404(100)$ & $326(23.2)$ & & $513 \pm 0.05$ & & $175(12.5)$ & $276 \pm 4.66$ & $151(10.8)$ & $237 \pm 4.49$ \\
\hline & 1 & Wet & $702(50.0)$ & $202(28.8)$ & 1.07 & $204 \pm 0.221$ & 0.23 & 99(14.1) & $122 \pm 0.321$ & $103(14.7)$ & $82 \pm 0.320$ \\
\hline & 2 & Dry & $702(50.0)$ & $124(17.7)$ & 0.08 & $254 \pm 0.032$ & 0.210 & $77(10.9)$ & $143 \pm 0.001$ & $47(6.7)$ & $111 \pm 0.121$ \\
\hline & & $\begin{array}{l}\text { Total } \\
\text { Occupation }\end{array}$ & $1404(100)$ & $326(23.2)$ & & $513 \pm 0.05$ & & $176(12.5)$ & $265 \pm 0.231$ & $150(10.7)$ & $193 \pm 1.001$ \\
\hline & 1 & Farming & $253(18.4)$ & $61(23.6)$ & $.03 *$ & $114 \pm 1.200$ & 0.012 & $38(15.0)$ & $32 \pm 0.020$ & $23(9.1)$ & $82 \pm 0.022$ \\
\hline & 2 & $\mathrm{C} /$ Servant & $184(13.1)$ & $30(16.4)$ & 0.11 & $36 \pm 0.020$ & 1.021 & $18(9.8)$ & $12 \pm 0.012$ & $12(6.5)$ & $24 \pm 0.330$ \\
\hline & 3 & Student & $335(23.9)$ & $128(38.2)$ & 0.07 & $85 \pm 0.001$ & 0.340 & $65(19.4)$ & $65 \pm 0.020$ & $63(18.8)$ & $15 \pm 0.001$ \\
\hline & 4 & Business & $292(20.8)$ & $14(4.8)$ & $0.01^{*}$ & $90 \pm 0.321$ & 0.111 & $5(1.7)$ & $41 \pm 0.021$ & $9(3.1)$ & $49 \pm 0.001$ \\
\hline & 5 & $\mathrm{H} /$ wife & $135(9.6)$ & $23(17.0)$ & 0.10 & $0 \pm 0.00$ & 0.0 & 0.00 & $0 \pm 0.00$ & $23(17.0)$ & $10 \pm 0.120$ \\
\hline & 6 & Fishing & $200(14.2)$ & $70(35.0)$ & 0.55 & $188 \pm 0.012$ & 0.943 & $58(29.0)$ & $143 \pm 1.002$ & $12(6.0)$ & $40 \pm 0.012$ \\
\hline & & Total & $1404(100)$ & $326(23.2)$ & & $513 \pm 0.05$ & & 184(13.1) & $293 \pm 0.003$ & $142(10.1)$ & $220 \pm 0.001$ \\
\hline
\end{tabular}

*Significant $(\mathrm{p}<0.05)$

\section{DISCUSSION}

Out of the overall prevalence and intensity of urinary schistosomiasis $23.2 \%$ and $513 \pm 0.05$ eggs $/ 10 \mathrm{ml}$ of urine that were recorded in this study, $\quad 30.0 \%$ prevalence of urinary schistosomiasis were recorded in Ribadu and intensity of $72 \pm 0.12 \mathrm{eggs} / 10 \mathrm{mls}$ of urine. While, Kabawa had the high intensity with $80 \pm 0.02$ eggs $/ 10 \mathrm{mls}$ of urine and $12.4 \%$ prevalence with less in Kangle $24 \pm 0.82$ eggs $/ 10 \mathrm{mls}$ of urine with $21.6 \%$ prevalence urinary schistosomiasis, with statistically significant difference $(p<0.05)$. Gender related prevalence and intensity showed $185(25.5 \%)$ and $289 \pm 4.66$ eggs/ $10 \mathrm{ml}$ of urine among male with $141(20.8 \%)$ and $206 \pm 4.49$ eggs $/ 10 \mathrm{ml}$ of urine. This report is in disagreement with that of Olalubi et al. (2013) who recorded high intensity of $S$. haematobium among females than males. These differences may be attributed to the facts that, males engaged intensively in water contact related occupation than female in the present study Area, this is also in contrast with the work of (Kabatereine et al., 2004 and Turrock et al., 2009) who recorded very low prevalence and intensity of $S$. haematobium in their studies. Meanwhile, this could be as a result of geographical differences and high water contact activities by the subjects in the study Areas, meanwhile, this is in consonance with the research carried out by (Biu et al., 2009; Shashie et al., 2015 and Salwa et al., 2016) who in their findings shown high prevalence of $S$. haematobium infection among males than females and contrary with the work of (Tohon et al., 2008; Samei et al., 2010; Ladan et $a l ., 2011)$ who reported high infection of urinary schistosomiasis among females than males.

Prevalence and intensity with respect to age is highest among age bracket 5-14 with $36.6 \%$, and $128 \pm 0.033$ eggs $/ 10 \mathrm{mls}$ of urine and lowest among age bracket 45-54 years old with 9.0\% and $42 \pm 0.005$ eggs $/ 10 \mathrm{mls}$ of urine, this finding is 
in concordance with the work of (Hottez et al., 2009) who reported high urinary schistosomiasis incidence among School-age children, Adolescents and young Adults, and also in line with the work of (Olalubi et al., 2013) who Page | 3582 reported age group $\leq 8$, between 8 -11 and 12-15 years old with intensity of $301 \pm 0.03,201 \pm 0.23$ and $103 \pm 0.22$ respectively. Analysis has further shown that, males and females have relatively equivalent percentage of infections with $25.5 \%$ and $20.8 \%$ respectively and Chi-square indicated no statistically significant difference $(p>0.05)$. The prevalence and intensity of urinary schistosomiasis with respect to sources of water indicate that, subjects fetching from River/Stream and from Borehole have the highest and the lowest infection with and $31.8 \%$ and $241 \pm 0.302 \mathrm{eggs} / 10 \mathrm{mls}$ of urine and $13.8 \%$ and $46 \pm 0.080$ eggs $/ 10 \mathrm{mls}$ of urine, and there was significant statistical difference $(p<0.05)$, this is in line with the previous work conducted in Kano State by Salwa, et al. (2016) who reported 16.7\% prevalence among those that depend on Streams and River water as their only sources of water. It is also in accordance with the report of (Kiran et al., 2016) who recorded highest and lowest $S$. haematobium infection among those that fetch from Streams and Boreholes as $60.0 \%$ and $17.6 \%$ respectively. Seasonal prevalence and predisposition factor play important roles in urinary schistosomiasis in which low prevalence of $17.7 \%$, with high intensity $254 \pm 0.032$ eggs $/ 10 \mathrm{mls}$ of urine while high prevalence $28.8 \%$ and low intensity $202 \pm 0.221$ eggs $/ 10 \mathrm{mls}$ of urine and reported in wet season. Prevalence and Intensity of urinary schistosomiasis was recorded to be moderately low in terms of occupation with $35.0 \%$ and $188 \pm 0.012$ eggs $/ 10 \mathrm{mls}$ of urine among fishers. Meanwhile, highest prevalence was among students 38.3\% with intensity of $85 \pm 0.001 \mathrm{eggs} / 10 \mathrm{mls}$ of urine, while, lowest prevalence and intensity were recorded among Business men $4.8 \%$ and $36 \pm 0.020 \mathrm{eggs} / 10 \mathrm{mls}$ of urine C/servants respectively and it has revealed significant statistical differences $(p<.0 .05)$, this finding was in accordance with the work of (Ololubi et al., 2013) who noted highest prevalence of urinary schistosomiasis among students than any other occupations, but disagreed with that of Dennis, et al. (2013) who reported highest prevalence of urinary schistosomiasis among farmers (36.2\%) and lowest among Artisans, this disparity could be associated with the facts that most of the students in the present study attend Day Schools which might have given them more chances to frequently visit streams and rivers for fishing and recreational purposes.

\section{Conclusion}

This study that was conducted among residence along River Benue Adamawa State, and has presented moderate prevalence and intensity of urinary schistosomiasis compare to other report in some places, meanwhile, predisposition factors like; community geographical differences, occupation, gender, water source and age were considered to be the major determinant factors for the infection.

\section{Recommendation}

With the reports portrayed in the results, treatment of the community residence especially the fishermen and school-aged children with prazequantel at least once a year, until the prevalence of the infection falls below a level of public health importance should be advocated.

\section{Acknowledgements}

The Authors really acknowledged the generous cooperation of Adamawa State Ministry of Health Yola, Zoology Department, University of Technology, Yola, community heads of the study area, research assistance, and all the participants for their commitment, willingness and support during the field work. 


\section{Conflict of Interest}

There was no any conflict of interest associated to this research, and it was sponsored by Nigerian Tertiary Education Trust Fund Page| 3583 (TETfund).

\section{REFERENCES}

Adebayo, A and Tukur, L. (1999). Adamawa State in Map.

Biu, A.A., Kol, H.B. and Agbado, E.T. (2009). Prevalence of Schistosoma haematobium infection in School Aged Children of Konduga Loccal Government Ares, North Eastern Nigeria. International Journal of Biomedical and Health Sciences, 5: 181184.

Chitsulo, L., Engels, D., Monlresor, A. and Savioli, L. (2010). Global status of schistosomiasis and its control, Acta tropical Journal, 7(3):41-51.

Cheesbrough, M. (2006). District Laboratory Practice, Second Edition. Part 1, Cambridge University Press.233-236.

Dennis, O.U., Celestine, O.E., Onwuliri, F.O.U., Osuala., Ikechukwu, N.S., Dozie, F.N., Opara and Ucheamaka, C.N. (2013). Endemicity of Schistosomiasis in some parts of Anambara State. Academic Journal of Medical Laboratory and Diagnosis, 4(5) 54-61.

Hotez, P.J. and Kamth, A. (2009). Neglected Tropical Diseases in Sub-saharan Africa: Review of their Prevalence, Distribution, and Disease Burden. PLOS Neglected Tropical Disease. 3: 412-414.

Hotez, P.J, Asojo O.A, Adesina AM. (2012). Nigeria "Ground Zero" for the high prevalence neglected tropical diseases. PLOS. Neglected Tropical Diseases. 6(5):54-59.
Kiran, S., Dalhatu, M. and Jindra, S. (2016). Current Status of Schistosomiasis in Sokoto, Nigeria. Journal of Parasite Epidemiology and Control, 4(3): 239-244.

Mostata, M.H., Sheweita, S.A. and Oconnar, P.S. (2009). Relationship between Schistosomiasis and Bladder Cancer. Clinical microbial Journal, 12(4): 97-111.

Ladan, M.U., Abubakar, U., Abubakar, K., Bunza, M.D.A., Nasiru, M. and Ladan, M.J. (2011). Gender and Age Specific Prevalence of Urinary Schistosomiasis in Selected Villages Near a Dam site in Gusau Local Government Area. Zamfara State, Nigeria. Nigerian Journal of Parasitology, 32; 57-61.

National Population Commission (NPC) (2006)

Olulabi, A., Oluwasogo, Olukunle, B. and Fagbemi. (2013). Prevalence and Risk Factors of Schistosoma haematobium Infections among Primary School Children in Igbokuta Village, Ikorodu North Local Government, Lagos State. IOSR Journal of Nursing and Health Science2(6): 62-68.

Kabatereine, N.B., Brooker, S., Tokahebwa, E.M., Kazbwe, F., Onapa, A.W. (2005). Epidemiology and Geography of Schistosoma mannsoni in Uganda, Implication for Planning Control.Journal of Tropical Medicine International for Health. 9: 372-380.

Samie, A., Nchachi, D.J., Obi, C.L. and Igumbor, E.O. (2010). Prevalence and Temporal Distribution of Schistosoma haematobium infections in the Vhembe District, Limpopo Province, South Africa. African Journal of Biotechnology, 42(9) 7157-7164.

Sturrock, H.J.W., Picon, D., Sabasio, A., Oguttu, D. and Robenson, E. (2009). Integrated Mapping of Neglected Tropical Disease; 
Epidemiological Findings of and Control Implications for for Northern Bahr-elGhazal State. Southern Sudan. PLOS Neglected Tropical Disease 3(2): 537-543.

Page | 3584

Shashie, G., Agersew, A., Sisay, G., Zeleke, M. and Berhanu, E. (2015). Prevalence of Urinary Schistosomiasis and Associated Risk Factors among Abobo Primary Children in Gambella Regional State, Southwestern Ethiopia: A cross Sectional Study. Journal of Parasite and Vector 8:215 Doi 10.1186/s13071-015-0822-5.

Salwa, D.,Hesham M., Jamaiah, I., Awatif, M. A., Abdulhamid, A.,Hany, S. et al. (2016). Prevalence and Risk Factors of Schistosomiasis among Hausa Communities in Kano State, Nigeria. Revista Instituto of Medicina Tropico Sao Paulo, 5(7): 112-132
Tohon, Z.B., Mainassara, H.B., Garba, A., Mahamane, A.E., Bosque-Oliva, E., Ibrahim M.L. et al. (2008). Controlling Schistosomiassis: Significant decrease of Anaemia Prevalence one Year After a single Dose of Praziquantel in Nigerian School Children. PLOS Neglected Tropical Disease 2: e241.Doi:10.1371/Journal.Pntd.0000241.

Vanderwerf, M..J., De Vlas, S.J., Brooker, S., Looman, C.W., Nagelkerke, N.J. et al. (2003).Quantification of Clinical Morbidity Associated with Schistosome infection in Sub-Saharan Africa. Acta Tropical Journal. 86(1): 125-139

WHO. (2018) Global Burden Disease Estimate Index, Geneva 